\title{
NATURE CONSERVATION IN ETHIOPIA
}

$\mathrm{M}$ OST people, even those with experience of other parts of Africa, think that wild-life should be able to 'take care of itself' in Ethiopia. In a country of some 400,000 square miles, with a total population of only some twenty millions, one might expect there to be plenty of room for man and for even the largest wild animals. However, many animals and their habitats have already suffered severely. In some regions those mammals with valuable pelts, such as the leopard, colobus monkey and various antelopes, have been almost exterminated, and intensive farming has left little room for wild-life in othors.

At the request of the Ethiopian Delegation to Unesco, a mission, headed by Sir Julian Huxley and including Prof. Th. Monod, Mr. Lloyd Swift, Dr. E. B. Worthington, and M. Alain Gille, was organized to visit the country. This it did in September 1963; the mission's report is dated December 27, 1963*. The party spent only some six days in Ethiopia; but as its members all had considerable experience of conservation throughout Africa they were able to produce a useful report, setting out general principles and not trying to work out the details of their plans.

The report shows how much Ethiopia has still to offer. Thore is a wider range of biological environments than in any other African country. The surface of the land ranges from $146 \mathrm{~m}$ bolow sea-level to a height of $4,620 \mathrm{~m}$, and includes desert as well as tropical rain forest. Not only is the natural history of great interest; Ethiopia has a inique cultural heritage. There is Aksum, with its

* United Nations Educational, Scientific and Cultural Organization The Conservation of Nature and Natural Resources in Ethiopia. Report by J. Huxley, A. Gille, 'Th. Monod, L. Swift and E. B. Worthington. Pp. 50. monuments dating from the third century B.C., and a wealth of Christian architocture from tho fourth century onwards.

At present it is difficult for visitors from abroad, including scientists, to study or enjoy all that Ethiopia has to offer. The mission recommends improvements in the transport system and in hotels for visitors who could help to finance the schemes proposed. It recommends improvements in education and training, and hopes that these can be made through the University of Addis Ababa, so that rescarch can be done which will show how conservation can be promoted. The mission recommends the creation of a group of National Parks and controlled wild-life areas, not only to conserve what is there, but also to encourage the breeding of largor stocks of many animals. Finally, it suggests the administrative machinery to ensure the working of its plans.

Ethiopia is the only country in Africa which has not, except for the brief period of Italian occupation, had a colonial phase. Often in other parts of Africa and Asia wild-life conservation has been due to the enthusiasm of the ruling powers rather than of the indigenous people. However, to-day we see, in newly independent countries like Kenya and Tanganyika, an encouraging realization of the importance of conservation among the people, and now in Ethiopia the value of their unique wild-lifo is also being appreciated. Perhaps Africa will not, after all, kecome so impoverished as many have feared. It is clear, however, that help from outside will long be needed, and that, as well as advice from Unesco missions, concrete financial assistance and the help of technical staff will also be required.

K. Mellanby

\section{BILHARZIASIS RESEARCH IN EAST AFRICA}

$\mathrm{T}$ HE saying, 'Prevention is better than cure', is perhaps truer of bilharzia than of many other infections. Even if an individual is cured of the infection, tissues and organs in the body may have been irroparably damaged. Prevention, or control, of bilharzia is difficult anywhere, but a reduction in the amount of transmission, that is, control, might be achieved by breaking the parasite cycle in its intermediate host (snail) stage or by treating everyone who is infected to prevent water becoming contaminated with schistosome eggs.

The first method probably offers a greater ehance of success since it does not require active co-operation of the population. If logistics and technical details of a campaign to kill snails can be overcome, and such a campaign is based on sound preliminary investigations of ecology and bionomics of the snail, it is possible that much can be done to control the infection. The agrement of the people must be obtained, but, apart from this and their co-operation in showing the control workers the whereabouts of all water bodies, the local population will not be inconvenieneed in such a schemo.

The East African Institute for Medical Research has prepared a pilot control scheme for an area of Sukumaland based on the knowledge which is now available as to 'whoro' and 'whon' urinary bilharziasis is acquired; it is hoped that help from outside agencies will bo availablo to promote the scheme prior to a bigger project in Sukumaland*. Such obvious details as the best methods of

* Eist African Common Services Organization. Annual lieport of the bist African Institute for Medical Research, 1962-63. Pp. 67. (Nwanza, Tanganyika: East African Institute for Medical Research, 1964.) $5 s$. applying molluscicide to ponds and the optimum time for application tre being investigated; but, until such a scheme is put into operation, its difficulties will not be apparent and therefore cannot be overcome. Previous work has suggested that, in Sukumaland, only ponds of a temporary nature are involved in tho spread of urinary bilharziasis, and that permanent bodies are of little or no importance. Field studies are in progress to eonfirm this.

Evidence has been obtaincd that children are the main souree of infection in urinary bilharziasis, but curative treatment on a large scale is not practicable owing to the toxicity of drugs available. When, however, treatment is given at intervals of a fow weeks (suppressive treatment). toxic offects are virtually eliminated, and, although the cure rate is much less than with a normal course of treatment, the egg output of individuals is considerably reduced and they are therefore less 'dangerous' from the public health angle.

A satisfactory treatment for bilharzia in hospital and dispensary outpatients has yot to bo found, but a compromisi between ac form of 'suppressive treatment' and the usual 'curative treatmont' might be suituble. 'The time-interval between injections is being reduced to try to increase the cure rate of suppressive treatment while. at the same time, overcoming the toxicity associated with curative treatments. The effect on the infection. rato of snails in artificial ponds of redueing the amount of urinary contamination added (such as might oceur in the field if a large-scale treatment of children wero instituted) is being investigated. It is hoped that, from this, information will emerge as to how much reduction of egg output 